This is a peer-reviewed, accepted author manuscript of the following research article:

Wahome, M., \& Graham, M. (2020). Spatially shaped imaginaries of the digital economy. Information Communication and Society, 23(8), 1123-1138.

https://doi.org/10.1080/1369118X.2019.1701696

Spatially Shaped Imaginaries of the Digital Economy 
This is a peer-reviewed, accepted author manuscript of the following research article:

Wahome, M., \& Graham, M. (2020). Spatially shaped imaginaries of the digital economy. Information Communication and Society, 23(8), 1123-1138.

https://doi.org/10.1080/1369118X.2019.1701696

\section{Spatially Shaped Imaginaries of the Digital Economy}

This paper examines spatial imaginaries and their ability to circumscribe and legitimate economic practices mediated by digital technologies, specifically, the practices of digital entrepreneurship. The question is whether alternative imaginaries and typologies of digital entrepreneurship can be included in how we view digital entrepreneurship in order to stimulate new practices and imagined futures. Our case studies of digital entrepreneurs in a number of African cities illustrate that popular and academic spatial imaginaries and discourses, for example those that cast the digital economy as borderless and accessible, do not correspond with the experience of many African entrepreneurs. Furthermore, enacting the metaphoric identities that coincide with these imaginaries and their discourses is a skillset that determines which (and how) actors can participate. They reflect the inherent coloniality of the digital, capitalist discourse. The tendency in the digital economy is to regard the entrepreneur persona, as realistic and global, rather than performative and particular to the Euro-American context in which these personas have originated. Our interviews of 186 digital entrepreneurs demonstrate that digital imaginaries and metaphors cannot be neutral and apolitical. In order to be inclusive, they should evoke a sense of multiplicity, heterogeneity and contingency.

Keywords: digital imaginaries, digital entrepreneurship in Africa, African entrepreneurs, knowledge economy and development, innovation in Africa 
This is a peer-reviewed, accepted author manuscript of the following research article: Wahome, M., \& Graham, M. (2020). Spatially shaped imaginaries of the digital economy. Information Communication and Society, 23(8), 1123-1138.

https://doi.org/10.1080/1369118X.2019.1701696

Introduction

Critical theorists, particularly of science and technology studies have demonstrated that imaginaries are an important part of the process of producing sociotechnical domains (Jasanoff \& Kim, 2009, 2016). Imaginaries are not neutral or apolitical; they are underlain by values and ideologies. Technological imaginaries often are pervaded by a particular view of modernity. This is evident in popular, policy and academic discourses on development. Analyses of situated modes of technology production often reveal that rather than being universal, these processes are particular and mediated by place (Haraway, 1988).

Over the last few decades, the digital economy has been viewed as a vehicle for economic development. so much so that the discourse around it has taken on the tenor of human rights language, urging inclusion into digital and ubiquity of digital technologies as means of reducing global inequality. Even these ideas about inclusion are not universal or neutral, they are linked to situated and particular ideological perspectives and interests. The assumption that digital economies are inclusive reveals a lack of engagement with geopolitical power geometries that affect consent and inclusion and are embodied in the use, design and deployment of digital technologies. In fact, at this moment in time scepticism around the digital economy is increasing in the public sphere (Rajão \& Duque, 2014) as society reckons with the various asymmetries that mediate how users and workers are apprehended within the system.

This paper is particularly interested in the power geometry that leads to the identification of some geographies with the production of technological knowhow (Massey, 1999, 2002), and others as sources of raw material and recipients of finished products. Africa is in the latter category; it is cast as a recipient of knowledge, rather than a source. Yet, African sites are not only evidence that these mythologies of modernisation can be reductive. 
This is a peer-reviewed, accepted author manuscript of the following research article: Wahome, M., \& Graham, M. (2020). Spatially shaped imaginaries of the digital economy. Information Communication and Society, 23(8), 1123-1138.

https://doi.org/10.1080/1369118X.2019.1701696

. Adoptions and production of digital technology reveal that heterogeneity, and hybridity abound, which rouses critique about linear, deterministic narratives about technology and society (Mavhunga, 2017; Odumosu, 2009). In company with other studies and critical reflections on digital imaginaries and their role in planning and future making, we analyse the providence of the digital production and entrepreneurship imaginary and its effects at African sites. In particular how the reification of a particular mode of digital entrepreneurship is illustrative of power geometry and how power affects the adoption of particular digital entrepreneurship practices.

Evidence that power geometry is entwined with the mythos of digital technology is the way that the design and development of commercial digital technologies is strongly associated with the Silicon Valley experience (Saxenian, 1996; Steiber \& Alänge, 2016; Suchman, 2011; Suchman \& Bishop, 2000). We illustrate how the globalised practices, language and organisational forms of digital entrepreneurship are expected to mirror the practices of Silicon Valley actors. We implicate the social scientific research and discourse that has digested the Silicon Valley experience into decontextualised business management and technology commercialisation theories and practices that are universally touted, taught and applied (Ngoasong, 2018; Welter, 2011). The digital knowledge economy imaginary, in particular, is one of the products of this discourse (de Ferranti, Perry, Lederman, \& Maloney, 2002; Obamba, 2012). The digital economy is seen as a potent means for achieving economic development. and as a vehicle for producing and disseminating locally apt and socially beneficial, digital technologies (Kaplinsky \& Keynes, 2011; Rajão \& Duque, 2014).

This global vision for reducing global inequalities using market mechanisms and including more actors into the knowledge economy often emerges from a broader neoliberal, modernising project that envisions the growth of cosmopolitan places around the world. Places that will approach each other in terms of modes of existence and other proximities 
This is a peer-reviewed, accepted author manuscript of the following research article:

Wahome, M., \& Graham, M. (2020). Spatially shaped imaginaries of the digital economy. Information Communication and Society, 23(8), 1123-1138.

https://doi.org/10.1080/1369118X.2019.1701696

(Harvey, 1989) and lead to the establishment of transnational elites (Mbembe, 2016b). The

thinking is that this globalisation will reduce global inequalities. Recent research illustrates

that digital technologies and economies can amplify the problems associated with the

globalisation of finance capitalism (Storm, 2018).

Increased financialisation exposes populations to exploitation and predatory inclusion (Storm, 2018) and an increased imbrication of governance and capital. Precarity of labour is another effect of the digital economy (Graham, Hjorth, \& Lehdonvirta, 2017). In these ways and others ${ }^{1}$, digital society can be an environment that reduces, rather than increases, agency. Yet, the imaginaries and discourses that are used to mobilise digital entrepreneurship as a social imperative, particularly in low income contexts often fails to capture this growing awareness of downsides, variable effects and potential risks. This is problematic because lowincome contexts are (even more) vulnerable due to the power asymmetry that is inherent in that status. In addition, it is vulnerable actors who are often left out of the decision-making about, planning for, as well as the imagining of the future. Thus, the imaginaries and metaphors that serve to propose a particular kind of digital entrepreneurship as a solution to social problems often fail to capture their perspectives. In this paper, we discuss the global power differentials that determine whose visions have power and how digital imaginaries interact with Africa's own visions and aspirations.

\section{Comparing Universal Discourse to Situated Practice}

Jasanoff and Kim (2009) who developed the concept of social technical imaginaries determine that they "reside in the reservoir of norms and discourses" (Jasanoff \& Kim, 2009). Thus, our methodology was informed by the rationales and methods of critical discourse

\footnotetext{
${ }^{1}$ On the socio-political front, digital technologies expose groups to propaganda, radicalisation and political manipulation (Sparkes-Vian, 2019; Woolley \& Howard, 2018)
} 
This is a peer-reviewed, accepted author manuscript of the following research article:

Wahome, M., \& Graham, M. (2020). Spatially shaped imaginaries of the digital economy. Information Communication and Society, 23(8), 1123-1138.

https://doi.org/10.1080/1369118X.2019.1701696

analysis. We analysed and developed an understanding of the relevant digital

entrepreneurship academic and policy discourse and how it connected to specific discourses on digital entrepreneurship in Africa. Like others who have conducted studies of sociotechnical imaginaries (Hsu, 2018; Sadowski \& Bendor, 2019) this consisted of a perusal of documents, including white papers, academic literature, media reports, and websites that convey imaginaries associated with the digital economy. For instance, Sadowski and Bendor who have stated that "documents are the medium most often used to construct and transmit sociotechnical imaginaries" (2019, p.547) similarly conducted an analysis of documents produced by IBM and Cisco in order to characterise the vision that was being developed around smart cities.

Africa's development trajectory is heavily influenced by international development institutions. Thus, we read documents produced by institutions like the World Bank, influential academic discourses on ICT4D. We also includedpopular and news media in order to develop a picture of how society saw the digital economy. As discussed in the introduction, this exercise revealed the dominance of a singular perspective on progress, economic development and the future. The interviews we conducted aimed to understand the applicability of these rationales and expectations in the contexts that African entrepreneurs find themselves in. Often studies dwell on the difficulties of digital entrepreneurship without considering whether participation is feasible or under what conditions it can and should occur.

Analysing this material produced thematic areas. These were: a thematic area concerned with entrepreneurial mindsets and motivations and clashes with their experience, asecond on freelancers as entrepreneurs, a third on digital markets and, a fourth on entrepreneurial ecosystems. The authors of this paper are members of a larger project team that travelled to field sites in East, South, Central and West Africa and conducted interviews 
This is a peer-reviewed, accepted author manuscript of the following research article:

Wahome, M., \& Graham, M. (2020). Spatially shaped imaginaries of the digital economy. Information Communication and Society, 23(8), 1123-1138.

https://doi.org/10.1080/1369118X.2019.1701696

with 186 African entrepreneurs. We identified potential, first-round interview candidates

through desk-based research and then used snowball sampling to connect with other

entrepreneurs in their networks. For this reason, we were pre-disposed towards interviewing

entrepreneurs who had met with some measure of visibility as a factor of their internet

present or the fact that they were identified by others in their networks. Each interview was

recorded and transcribed and field notes captured other observations and contextualising

information. After transcription, each interview was uploaded to NViVo and coded according

to the themes, concepts, and categories unearthed by the critical discourse analysis.

In this paper, we seek to examine whether entrepreneurs' individual visions resemble the overarching imaginaries described in the documents, whether their practices match these imaginaries and which backgrounds are best suited to enacting the personas associated with the imaginaries. Individual aspirations are informed by imaginaries. Reflecting on commonalities between aspirations reported to us in interviews allows us to develop an idea of imaginaries that are specific to locales. It is to be expected that because of Africa's status, these imaginaries would be hybrids of expectations created elsewhere and local experiences and values.

\section{The Knowledge Economy Discourse}

Our discourse analysis is interested in the origin of policy thinking around innovation and digital entrepreneurship, and much of it is embedded within a wider knowledge economy framework. We determined the influence of particular academic discourses through our own familiarity with the discourse, which is supported by citation records. For instance, Annalee Saxenian's work is cited over 28,225 times. Henry Etzkowitz who has written about university—industry linkages has been cited 41,552 times. Most studies of innovation systems, at both the national and regional levels have concentrated on Euro-American 
This is a peer-reviewed, accepted author manuscript of the following research article:

Wahome, M., \& Graham, M. (2020). Spatially shaped imaginaries of the digital economy. Information Communication and Society, 23(8), 1123-1138.

https://doi.org/10.1080/1369118X.2019.1701696

settings (Fagerberg, Lundvall, \& Srholec, 2018; Lundvall, 2010). Thus, the wider discursive

context of this study is a social scientific and policy discourse with a linear telos of progress

that links development to a neoliberal, industry-led perspective on technology production and

social advancement. Although these researches have emerged from different disciplinary

domains, they developed into a seemingly coherent framework of the knowledge economy

imaginary. For instance, Freeman's research into the research and development (R\&D)

infrastructures of the U.S. and Japan has been codified in the documents of powerful,

developmen organisations like the World Bank, the OECD and others as best practices for

establishing similar success in other locales (e.g. OECD's Frascati and Oslo Manuals, 2018).

Lundvall has built on Freeman's work to develop National Innovation Systems (NIS)

framework, which resonates with Porter's work on national competitive advantage. At the regional scale, Michael Porter's research on clusters and competitive advantage, alongside Annalee Saxenian's research on the technological and economic success of Silicon Valley have been understood as blueprints for how to stimulate regional economic development using digital entrepreneurship. Etzkovitz and Leydesdorff's triple helix framework which seeks to unite university research, industry interest and government policy is based on the experience of Stanford and Silicon Valley and Boston's Route 128 corridor (Etzkowitz \&Leydesdorff, 1995). Tech parks and university technology transfer offices around the world are linked this scholarship. Incubators and co-working spaces in global cities aim to facilitate the clustering that Porter and Saxenian have identified as important for the success of innovation ecosystems. Clayton Christensen, is responsible for bringing Schumpeter's ideas about creative destruction into the popular imaginary through the term disruption with his book The Innovators Dilemma. In fact, many of the ideas generated by these scholars have become mainstreamed into the popular, modernist imaginary. 
This is a peer-reviewed, accepted author manuscript of the following research article:

Wahome, M., \& Graham, M. (2020). Spatially shaped imaginaries of the digital economy. Information Communication and Society, 23(8), 1123-1138.

https://doi.org/10.1080/1369118X.2019.1701696

Under the current discursive regime, the knowledge economy is considered the ideal imaginary and economic framework for contemporary society (de Ferranti et al., 2002). The knowledge economy imaginary specifies the kind of knowledge and talent accumulation that is valued: science, technology, engineering, and mathematics (STEM) and social sciences that have been recruited in service of these disciplines are idealised as most desirable. Institutions of higher learning (IHLs), public and private sector institutes and think tanks are considered the key and authoritative sites of technoscientific knowledge production (Etzkowitz \& Leydesdorff, 1995; Freeman, 1995, 2003; Lundvall, 2010). In this imaginary, they are also the producers of the requisite human capital for a functioning knowledge economy. The role of entrepreneurs and firms in the production of commercial technologies has also come to receive increasing attention. This in part is as a result of the success of Silicon Valley startups and their founders who are seen as evidence of the benefits of the knowledge economy (Christensen, 2013; Saxenian, 1996, 2006). As a product of STEM related fields, digital technologies have prominence within the framework of the knowledge economy. Christensen's and Saxenian's research points to firms and the entrepreneurs within them as fundamental units within this knowledge economy framework. Their experiences, activities and impact have been a proof-of-concept for the digital knowledge economy imaginary.

These economies are preceded by capital, infrastructure, and talent accumulations and investments (Porter, 1990; Sala-i-Martin, Bilbao-Osorio, Blanke, Hanouz, \& Geiger, 2011). Srinivas and Sutz (2008) warn that viewing development as "a long, linear march...distracts us from how innovation actually emerges in practice" ( $p$ 130). The research on developing country innovation has tended to focus on poverty alleviation and access to technology rather than studies on situated modes of entrepreneurship. Technology systems in developing 
This is a peer-reviewed, accepted author manuscript of the following research article:

Wahome, M., \& Graham, M. (2020). Spatially shaped imaginaries of the digital economy. Information Communication and Society, 23(8), 1123-1138.

https://doi.org/10.1080/1369118X.2019.1701696

countries are still viewed as idiosyncratic which is reflected in the literature where situated

innovation is described using prefixes like 'below-the-radar' or 'jugaad'.

It is taken for granted in development discourse that inclusion into the knowledge economy and enactments of a particular kind of digital entrepreneurship is the ideal approach for advancing societies and reducing poverty and dependency. The institutions with the authority to advance this vision have done so. Indeed, despite the apparent success of the academic critique of modernization theory, technological solutionism and the failure of modernising imperatives in development practice (Hsu, 2018; Mosse, 2005; Suchman, 2011), the rationales that govern a top-down approach towards development is one that seeks to reproduce Euro-American development processes in so-called under-developed contexts. This translates into an emphasis on the reification of process, with an expectation that this will lead to similar outcomes in new locales. The excerpt below summarises the World Bank's perspective.

Technology-driven changes are radically transforming the world and enabling developing countries to leapfrog decades of "traditional" industrial development. But disruptive technology also increases the stakes for countries, which cannot afford to be left behind (Pazarbasioglu, 2018).

The excerpt echoes many of the scholarly ideas around competitive advantage, modernisation and development that underpin much of the thought around the role of innovation in reducing underdevelopment and global inequalities. Silicon Valley is a highly-researched exemplar of the digital knowledge economy and thus its representative imaginary (Carver, 2010; Suchman, 2011).

\section{Appropriating the Silicon Valley Imaginary}

Scholarship on imaginaries indicates that imaginaries derive their legitimacy from the 
This is a peer-reviewed, accepted author manuscript of the following research article:

Wahome, M., \& Graham, M. (2020). Spatially shaped imaginaries of the digital economy. Information Communication and Society, 23(8), 1123-1138.

https://doi.org/10.1080/1369118X.2019.1701696

authority of those to whom the vision belongs (Jasanoff \& Kim, 2009; Sadowski \& Bendor,

2019). This factor can overshadow criteria such as relevance, ingenuity, importance or

usefulness (Selin, 2008). This paper demonstrates that powerful imaginaries can generate an impetus for their adoption even when they are situationally inappropriate and this can generate perverse, unintended consequences (Graham, 2015). For instance, in the interest of acquiring the legitimacy bestowed by an imaginary, actors can be incentivised to fabricate promises and compliance with expectations (Pollock \& Williams, 2016).

Since the social scientific, policy and business discourse of recent years has made Silicon Valley emblematic of modernisation, technofuturism and business success, those with the authority to do so prescribe its practices and perspectives (often uncritically) as a means for stimulating a digital, knowledge economy (Suchman, 2011). Aside from this element of prescription by policy institutions, the Silicon Valley imaginary is powerful because of the popular mythology that has developed around it. Anyone exposed to it is encouraged to view the Silicon Valley experience as the apogee of technology production and commercialisation. This is to be expected given the ability of Silicon Valley entrepreneurs to produce globally utilised technologies, some of which have become the primary means of transmitting information worldwide, and are themselves a means through which the mythology is spread.

The materialities and enactments differ slightly from place to place to reflect the contexts in which they are embedded but the underlying imaginary is the same. Africa's digital entrepreneurs are inspired by Silicon Valley and seek to emulate it. This is signalled by the monikers developed for local ecosystems, for example Silicon Savannah in Nairobi, Kenya and Silicon Mountain in Buea, Cameroon. When asked to account for this, entrepreneurs indicate that they have no other points of reference. 
This is a peer-reviewed, accepted author manuscript of the following research article: Wahome, M., \& Graham, M. (2020). Spatially shaped imaginaries of the digital economy. Information Communication and Society, 23(8), 1123-1138.

https://doi.org/10.1080/1369118X.2019.1701696

It's the only example we have. It's the only clear example we have, so I've become less of a critic when Africans, especially African start-ups follow the Silicon Valley model because it's the only example we have (Technologist in Maputo).

The fact that they rely upon this imaginary to navigate their understanding of digital entrepreneurship means that they often base their expectations of success on Silicon Valley milestones. Entrepreneurs thus seek to acquire mindsets and attributes that they associate with the imaginary.

All of this is dependent on faith in the universality of inclusivity. One of the key narratives around digitisation is that it creates even playing fields with respect to access to information and markets; that digital entrepreneurs and their customers inhabit a borderless, no-man's land in cyberspace where they can freely engage in commerce. This imaginary belies the fact that participation requires actors from around the world to assimilate into and be educated into a particular worldview (Obamba, 2012). Even then, familiarity with this ecology of knowledge does not necessarily guarantee access and success. This is often determined by social status and networks. Based on the interviews, the idea that digitisation provided access to a global market proved to be durable. Many respondents espoused a belief that they could gain access to a broader 'global' arena if their ideas were good enough, products robust and that they had the requisite entrepreneurial skills and knowledge. They often explained failure in terms of shortcomings of their environment, rather than the asymmetric modalities of inclusion inherent in the digital economy as a mechanism for globalisation

An entrepreneur that built custom solutions in Nairobi, had absorbed the message that selling custom-software to business clients was not as successful as selling a mass market services. 
This is a peer-reviewed, accepted author manuscript of the following research article: Wahome, M., \& Graham, M. (2020). Spatially shaped imaginaries of the digital economy. Information Communication and Society, 23(8), 1123-1138.

https://doi.org/10.1080/1369118X.2019.1701696

So we custom build solutions, which is not very sustainable I must admit. [...] We do things across sectors, we work with health, we work in education, we work in agriculture, in government, we do things, we build big projects, small projects and stuff, so we're still trying to figure out where. But the clients, our client base is not mass market, it's not for everyone, the stuff we build, so for that reason it becomes a bit tough to kind of produce that one thing (Entrepreneur in Nairobi).

The question of business sustainability however is dependent on how much revenue the business generates. The assumption that markets can be breached simply through the introduction of digital technologies and certain entrepreneurial perspectives proved to be naive. After years of experience, some entrepreneurs are able to be reflective about the promises of the imaginary:

The whole buzzword of a new digital economy globally, and the internet, and this whole principle of net neutrality allowing you to have access, the way everyone else will have access.... Fundamentally, that is not the truth in parts of the continent. So, there's already so many dynamics that makes it nearly impossible for you to truly innovate based on these weak fundamentals, and then take on a global competitor. If these basic cost structures don't change it will be really difficult to even scale that early barrier to get a true breakthrough innovation and then there's the [electric] power challenge, obviously, some broader macro issues (Hub manager in Accra).

While entrepreneurs in Silicon Valley might have been able to access the financial backing to overcome localised infrastructural constraints or absorb the costs of doing business internationally, financing is not as readily available for African entrepreneurs. A primary competitive advantage, a la Porter, of Silicon Valley firms is their ability to attract patient capital for rapid international scaling with no expectation of returns for decades. .

Offering an alternative approach to growth, a section of entrepreneurs interpreted scaling as a step-wise expansion. One had to gain a local foothold before they grew out with their domain. Some entrepreneurs with this view were uncritical of the idea that technologies 
This is a peer-reviewed, accepted author manuscript of the following research article:

Wahome, M., \& Graham, M. (2020). Spatially shaped imaginaries of the digital economy. Information Communication and Society, 23(8), 1123-1138.

https://doi.org/10.1080/1369118X.2019.1701696

could be universally appropriate, rather they saw their products as particularly suited to the

African market and had no expectation of 'going global'. They often characterised Africa in simplified ways that reflected a sublimation of the discourse around the digital economy and its ability to flatten and dismantle barriers to trade. The heterogeneity of the environment and the differences in markets were glossed over in favour of an imaginary that saw Africa as a monolith, and easy to traverse.

It's always been Africa, so it's mobile, it's borderless, it's always been Africa. When we started off we felt that, when you think about somebody who is living in Kenya and discovered this whole Smart Phone thing, it influenced my vision of the company and I was living in Kenya, I was in Nigeria and I was travelling around across the continent and I knew what the different options were, where and that's really how we approached the opportunity. It's an African opportunity I think (Entrepreneur in Lagos).

Other entrepreneurs reported that regional expansion is particularly difficult; aside from the infrastructural limitations whose importance varies from one context to the next, regulatory and logistical issues were also reflected in cross-border ecommerce. Digitisation did not always ameliorate these conditions. Yet entrepreneurs consistently told us of their plans to set up shop in neighbouring countries.

I see Rwanda more like a giant proof of concept, then when it's time to go out there and I'm like trade with those countries. First of all I have a system, I have staff that understand what we do. So it is about replicating there and then finding our (numbers) and then we can go like-- by the end of 2018, my plan is to actually to start looking at various African capitals (Entrepreneur in Kigali).

This is not to say that there are no digital enterprises in Africa that are successful at regional and global levels. There were many firms, particularly in the B2B (business to business) area that had international customers. These were largely in the minority, as is the case in Silicon Valley. The odds of success are even lower in African settings yet the startup firm and its 
This is a peer-reviewed, accepted author manuscript of the following research article:

Wahome, M., \& Graham, M. (2020). Spatially shaped imaginaries of the digital economy. Information Communication and Society, 23(8), 1123-1138.

https://doi.org/10.1080/1369118X.2019.1701696

innovation ecosystem continue to be peddled by policy institutions and governments as a

means for local economic development. Contexts have their own internal visions, logics, interests, values and agentive processes. For instance, the fact that Kenya's much touted MPesa has not spread much beyond Kenya's border is an indicator of just how localised use cultures can be. Imaginaries, as well as technologies, are universal if actors in a variety of contexts are able to appropriate and make them relevant to their needs (Mbembe, 2016; Tsing, 2005).

\section{Dreamscapes of Modernisation}

Like Silicon Valley, Africa is not just a spatial location-it conjures up particular imagery, discourse and expectations. Scholars of economic development that perpetuate a linear view of societal development often also articulate an underlying view that locates modernity outside of Africa (Balakrishnan, 2016). As a result, Silicon Valley and African imaginaries are opposites. Silicon Valley epitomises capitalist modernity, while Africa is often cast as an observer and recipient, rather than a participant in the history of knowledge production. This modernising perspective mistakenly assumes that contexts are clean slates, without preexisting imaginaries, preferences, and knowledge forms.

Advocacy for local entrepreneurship is often invoked as a more progressive attitude on bringing African society closer to modernity through technological advancement. Africa's entrepreneurs are cast as solving Africa's development problems using market based incentives and imperatives (Kaplinsky \& Keynes, 2011). Some entrepreneurs echoed this perspective in the responses about their vision.

I was reading an article, it's called the Pull and Push Strategy. So pretty much the pull strategies is like pretty much what Uber does: provide money, bring [in] your own experts, try to adapt. In cultures where push strategy works, they [users] push you from 
This is a peer-reviewed, accepted author manuscript of the following research article: Wahome, M., \& Graham, M. (2020). Spatially shaped imaginaries of the digital economy. Information Communication and Society, 23(8), 1123-1138.

https://doi.org/10.1080/1369118X.2019.1701696

the bottom to grow. By doing that, you actually incorporate all the - how can I say it? All the country's real needs in terms of the values. It's more adapted to the market. That's why you have, for example, that Uber has had to change strategy in Kenya where drivers accept cash. They didn't just come and have you have to pay with your credit card (Entrepreneur in Nairobi).

This interview excerpt demonstrates the extent to which the discourse travels, and also how knowledge production is informed by global interaction. The development ecosystem has demonstrated an awareness that top-down development interventions are failing and failing because they do not account for local agency and preferences.

The digital entrepreneurs in Africa that have appropriated the rhetoric of the startup imaginary have to reckon with variations between their experience and expectations.

In the TED Talks event on Vienna, Marcelo Shima. I can share the link with you. And he said something cool that is, in more 20 years Africa will be beating all those countries. We are the country that has more young people. We are the best -- our capability of thinking is increasing every day and we have to find like different solutions for everything. So anyone's explaining, talking about debts all the time. So that's why I say us as Africans that are coming from an emerging market, we have a big advantage, because they already have everything. So they don't have to think how to solve the problems. We have the skills, to like we'll be able to pay the bills tomorrow. So if they took the problems to Africans or emerging markets or India or South America or something like that, I think what would happen will be okay, we'll just have to cry and they will help us and we need those problems. Sometimes I think that's the thing that make us like going on a different pace (Entrepreneur in Maputo).

The rationales of the competitive advantage doctrine are evident in the excerpt above. The excerpt also reveals a line of thinking that was espoused by a number of respondents, that Africa's social problems were actually a form of competitive advantage. For instance, through this lens, Africa's youth unemployment bulge becomes a potential labour force. 
This is a peer-reviewed, accepted author manuscript of the following research article:

Wahome, M., \& Graham, M. (2020). Spatially shaped imaginaries of the digital economy. Information Communication and Society, 23(8), 1123-1138.

https://doi.org/10.1080/1369118X.2019.1701696

Some firms generated their entrepreneurial narratives out of this idea that social problems

were entrepreneurial opportunities.

I think a very good example of that is Andela in Nigeria. Andela basically they train coders and place them. They find people who are already coding or people, who have never coded, train them in coding and then outsource them to different companies worldwide. They think it's an issue that other places don't necessarily seem to get it like we have all this manpower in Africa and the tech world is booming. There's not enough people to fill all of those spots at "lower wages." So, I think they found an opportunity and they took it. They didn't try to become another tech start-up and hire people for them. They're training people to hire out which it's a very interesting perspective. (Entrepreneur in Kampala)

These narratives are also evident in policy and academic scholarship which provide an evidentiary basis for this assertion. Some of Africa's entrepreneurs generated an imaginary where Africa's positionalities and problems allowed them to create technologies that are situationally relevant, but globally useful.

But I think an opportunity a lot of Africans are waking up to now is that looking inwards tends to be very advantageous because we seem to solve problems the rest of the world either doesn't have or it's not so big of a nuisance that they cared enough to solve. But then when we solve them, the rest of the world wants to use them. [...] company called Flutterwave which is kind of like the middleman between payment services [...] what they are doing right now is becoming the middleman for all of these international companies who try the "African markets" because Africa is not a monolith. They are becoming the middleman between all of these companies who have tried to implement their Silicon Valley model in Africa and failed. So, like they integrate whatever their platforms are into Flutterwave and Flutterwave already has the integration with the local governments. I think that is brilliant. We tried to solve a local problem first and inadvertently, solve problems for the rest of the world. I think a lot more African entrepreneurs and start-ups need to start looking inwards. Yeah, because the potential is huge (Tech person in Maputo). 
This is a peer-reviewed, accepted author manuscript of the following research article:

Wahome, M., \& Graham, M. (2020). Spatially shaped imaginaries of the digital economy. Information Communication and Society, 23(8), 1123-1138.

https://doi.org/10.1080/1369118X.2019.1701696

Euro-America is often cast as the centre to which other places are gravitating. The

excerpt represents a perspective presented by some entrepreneurs that reverses this trajectory but uses similar frameworks of technological determinism and geographical exceptionalism. The vision of a global knowledge economy often considered positive and neutral is in fact linked to the spread of particular ways of looking at the world (Mbembe, 2016). A term like 'global village', which is often used in the context of digital economy seeks to evoke a sense of the inclusion and communality that is possible through digital connectivity. It fails to convey the relational asymmetry and power geometry that is inherent in envisioning how the world should work (Jasanoff \& Kim, 2016; Selin, 2008). Digital entrepreneurs who seek to participate in the global startup arena modelled after Silicon Valley are constrained by its imaginary, particularly since there is an assumption that this imaginary can be universalised. This assumption means that alternatives are not investigated or are represented as variations of a stable model.

\section{Asymmetry and its Effects on Appropriation of the Model}

The various imperatives and motivations to adopt the digital entrepreneurship imaginary failed to reckon with the fact that some of the differences in entrepreneurs' experiences would be affected by their context. A context that includes the fact of asymmetrical power geometry that stems from their placement in so-called peripheral places.

\section{Distance from Capital}

We have already conveyed that entrepreneurs often cited a lack of ready capital in their ecosystems as their primary challenge. Proximity to capital is a factor of power geometry. Net capital and asset flows have historically flowed from Africa to the West. The persistence of this dynamic is often not referenced in considerations of whether the financing 
This is a peer-reviewed, accepted author manuscript of the following research article:

Wahome, M., \& Graham, M. (2020). Spatially shaped imaginaries of the digital economy. Information Communication and Society, 23(8), 1123-1138.

https://doi.org/10.1080/1369118X.2019.1701696

environments that have developed elsewhere were feasible in African environments. As a

result of the lack of venture capitalists Africa's digital entrepreneurs look outward to the

places where these financing models exist.

It is thought that it takes a particular ecology of knowledge and practice to finance the research and development of technology — a knowledge ecology that is not only scientific, but also has a particular perspective on capitalist relations. The narrative that digitisation created a unified global, digital village led entrepreneurs to have an expectation that geographic distance from these sites could be overcome. The CEO of a startup in Johannesburg expressed her view that Africa was still seen through an extractive, rather than investment lens.

\footnotetext{
You can't raise money over an idea. We are not Silicon Valley. [In] Silicon Valley you can do that. Even if you've got a Silicon Valley idea they don't want it, because how do they get money out? They'll be far more confident if you're actually off shore and you're leasing that software to Africans. Those things you only learn over time. Then maybe if you are selling basic exports. [...] Because we're in Africa and labour is cheap. You want the benefit of the cheap product, but you do not want to take the risk. (Entrepreneur in Johannesburg).
}

In her experience potential investors preferred to deal with companies that were African in the sense that they had African customers and used local labour, but were located outside the continent. The respondent also noted that it was partly an issue of trust. Other kinds of 'export' enterprises, however, particularly those that exported raw materials and/or basic manufacturing had no trouble attracting global investors. They fit it with the imaginary of Africa in a way that the imaginary of the start-up economy did not 
This is a peer-reviewed, accepted author manuscript of the following research article: Wahome, M., \& Graham, M. (2020). Spatially shaped imaginaries of the digital economy. Information Communication and Society, 23(8), 1123-1138.

https://doi.org/10.1080/1369118X.2019.1701696

Assimilation

The question of risk seemed to be mitigated by creating the impression of similarity with modern places. Entrepreneurs often referenced investor interest as the impetus for their decision making, even when they were generating revenues and appeared to be selfsufficient.

I mean the investors-- it gave investors the confidence to invest more money because then we had some visibility into our revenues, because we had these contracts that were recurring contracts but with a recurring model. (Entrepreneur in Lagos)

Entrepreneurs understood that embodying the spatial arenas that resonated with venture capitalists they might be able to attract capital.

\section{Dissimulation}

When legitimacy is derived from building expectations and connecting to the imaginaries of the powerful (Borup, Brown, Konrad, \& Van Lente, 2006; Garud, Schildt, \& Lant, 2014) there is an opportunity for fabrication to become an entrepreneurial strategy (Borup et al., 2006; Garud et al., 2014). Including fabricating identities and narratives that resonate with the prevailing framework. "Economic relations and practices 'of all kinds are influenced and structured by moral dispositions and norms ... and those norms may be compromised, overridden or reinforced by economic pressures" (Wiegratz, 2010, p 125). The story of Elizabeth Holmes and Theranos is an extreme example of the moral produced by this regime. The irony is that hyperbole and short-cuts are incentivised by the imperatives of venture capital which demand entrepreneurs make inflated promises and quickly build high-value, capital intensive enterprises. In Maputo, a start-up entrepreneur who had been successful in attracting investor interest admitted that despite the definitiveness with which they 
This is a peer-reviewed, accepted author manuscript of the following research article: Wahome, M., \& Graham, M. (2020). Spatially shaped imaginaries of the digital economy. Information Communication and Society, 23(8), 1123-1138.

https://doi.org/10.1080/1369118X.2019.1701696

communicated their successes to investors, they were still in a phase where they were testing strategies.

Everything we are doing, expansion, no expansion we are trying. I don't what you call to be successful but we are still in the trying phase. So that will be on record, maybe a few years from now we'll have a different conversation (Entrepreneur in Maputo).

They also indicated that their regional expansion was primarily a strategy for demonstrating traction to investors, rather than the result of demand. By creating a presence in a new country they were able to claim that they had expanded to a number of countries, even though this was not representative of a growing customer base.

A recent example of Jumia, billed as Africa's Amazon is particularly illustrative of the perverse incentives that abound. On May 9, 2019, a month after Jumia's successful IPO on the New York stock exchange the Financial Times and other media outlets reported that a controversial 'short-seller' had uncovered discrepancies in Jumia’s financial reporting, causing its shares to plummet:

Citron Research, a short seller, said on Thursday that it had obtained a confidential presentation made by Jumia to investors in October 2018, and that there were "material discrepancies" between this presentation and the numbers reported by Jumia in its IPO filing in April. Citron alleged that Jumia inflated its active customer and active merchant numbers by 20 to 30 per cent, and that 41 per cent of its deliveries were either returned, not delivered or canceled (Munshi \& Pilling, 2019).

Jumia is representative of the idealised African startup firm, which is an amalgam of Silicon Valley tropes and a modernising narrative about Africa. Jumia's entrepreneurial narrative was embedded in the mythology of what digitisation could do for African commerce-it billed itself as Africa's Amazon, while being registered and incorporated in Germany. The core of their questioning was Jumia's user numbers — other ecommerce firms were having difficulty 
This is a peer-reviewed, accepted author manuscript of the following research article: Wahome, M., \& Graham, M. (2020). Spatially shaped imaginaries of the digital economy. Information Communication and Society, 23(8), 1123-1138.

https://doi.org/10.1080/1369118X.2019.1701696

in expanding their user base. The fact that it is a short seller that has allegedly exposed

Jumia's false narratives is indicative of the incentives for deception that are embedded in the startup/venture capital model. By causing Jumia's shares to plummet, the accuser stood to benefit, while Jumia's investors would have the opposite incentives. Thus, the legitimacy conferred by the startup imaginary often has very little to do with actual entrepreneurial or technological skillsets.

\section{Alternative Visions}

The rhetoric around digital entrepreneurship produces a specific affect; it evokes particular expectations around how actors behave, speak, cognize opportunity, success, value and failure. Some of these expectations are a product of the context in which they were developed, namely Silicon Valley. When transplanted, this place-based imaginary can be accused of creating hyped expectations and inducing an affective 'cruel optimism' (Berlant, 2011). Cruel optimism refers to a situation where that which is desired becomes an impediment to individual and collective progress (Berlant, 2011). This situation is evident in digital entrepreneurship arenas in African cities, where actors, particularly those in the early stages of their digital entrepreneurial journey hold expectations and aspirations that are unlikely to unfold as they expect.

Current metaphors and visionings of sociotechnical imaginaries are constricting to practitioners of digital entrepreneurship in Africa because they do not take their positionality into account. Although Africa might seek to participate in global patterns of consumption, its positionality is one of scarcity (Mbembe, 2002) and asymmetric power geometry. Those who seek to be included in globalising economic regimes have to reckon with metrics that incentivise them to structure their activities to fit within certain expectations. As a collective, 
This is a peer-reviewed, accepted author manuscript of the following research article:

Wahome, M., \& Graham, M. (2020). Spatially shaped imaginaries of the digital economy. Information Communication and Society, 23(8), 1123-1138.

https://doi.org/10.1080/1369118X.2019.1701696

entrepreneurs displayed nuanced understandings of the opportunities in the various scales of

digital economies, some actors are able to react strategically (Graham, 2015). Experienced

actors understand that even though the logics might not be fitting, they do not have the power to alter them (Abbott, 2005) and are beholden to them. Digital entrepreneurs often have to communicate competency in Silicon Valley-style tropes and approaches to business in order to be seen as legitimate, whether or not that praxis makes any sense for them (Carver, 2010; Steiber \& Alänge, 2016). Actors are acting within circumscribed ideas about who can participate and how (Bourdieu \& Wacquant, 1999).This for some, is an acceptable status quo since the logics are structured so that the exclusions are seen as selecting for knowledge and expertise (Bourdieu \& Wacquant, 1999; Pager \& Pedulla, 2015; Pager \& Shepherd, 2008), and they are able to enjoy the privileges that emerged from proximity to legitimacy.

Not every digital entrepreneur is preoccupied with the Silicon Valley model of fastgrowth, high value entrepreneurship. A number of entrepreneurs focus on their products, generating revenues and growing their customer base. In advocating for the creation of space for alternative imaginaries, the question that arises is what those alternatives might be. The answer is that each of our case studies offers an exemplar. The particularisation of the experience of digital entrepreneurs in each city was clear, even as they referenced the Silicon Valley archetype. The appropriation of ideas and artefacts can occur through processes of syncretism, rather than disruption of old ways of doing (Odumosu, 2009). This involves absorbing imaginaries into to pre-existing worlds. The longer actors are involved in trial and error experiments on how to resolve their particular concerns, in their particular environments, the better able they are at navigating the paradox between the vision and its enactment. Ideally, entrepreneurs would not be constrained by their inability to change the vision. Our eagerness to extend participation in the digital economy blinds us to the fact that 
This is a peer-reviewed, accepted author manuscript of the following research article:

Wahome, M., \& Graham, M. (2020). Spatially shaped imaginaries of the digital economy. Information Communication and Society, 23(8), 1123-1138.

https://doi.org/10.1080/1369118X.2019.1701696

we are dealing with plurality and that imposing mechanisms for development is another

means through which pre-existing asymmetries are reinforced and expanded.

\section{Conclusion}

We have connected the startup imaginary with discourses that can mythologise science, modernity and rationality. This mythology has a geographic component, locating ideal forms of digital entrepreneurship in Euro-America. The digital entrepreneurship imaginary that emerges from this worldview is pervasive. The links between how society imagines digital society and academic and policy discourses are clear. Thus, academics and policy actors should not perceive imaginaries as neutral metaphors. An awareness that they hold politics and values that are emblematic of their geographic origins means that they should be conceived and deployed with care. Particularly when they are deployed, not as theory or thought experiment, but with the intention of providing a blueprint for restructuring societies for development. Power geometry is also inherent in the patterns of appropriation of ideas and artefacts. For instance, the pervasiveness of the assumption that knowledge transfer generally travels from North to South, even when Southern geographies have been pivotal in the development of that knowledge.

The spread of these imaginaries relies on fictions about their neutrality and universality (Katz, 2014). The visions of the powerful are performed and perpetuated whether or not they are representative of everyone's (including the majority's) experience (Selin, 2008). In order for progress to work for every society it is necessary to ensure that claims of universality do not foreclose on the development of localised alternatives and hybrids. As academic work (re)turns to contemplating futures and the policy realm becomes interested in anticipatory governance (Selin, 2008), it is necessary to examine whether these visionings are taking place 
This is a peer-reviewed, accepted author manuscript of the following research article:

Wahome, M., \& Graham, M. (2020). Spatially shaped imaginaries of the digital economy. Information Communication and Society, 23(8), 1123-1138.

https://doi.org/10.1080/1369118X.2019.1701696

with targeted groups or 'at' them (Neveling, 2017). The danger is that power differentials

induce perverse incentives and predatory inclusion (Dy, 2017; Dy, Martin, \& Marlow, 2018;

Wiegratz, 2010).

\section{References}

Balakrishnan, S. (2016,). Pan-African legacies, Afropolitan futures: A conversation with Achille Mbembe. Transition: An International Review. (April 1, 2016).

Berlant, L. G. (2011). Cruel optimism. Durham, Durham [N.C.] ; London: Duke University Press.

Carver, T. (2010). Materializing the Metaphors of Global Cities: Singapore and Silicon Valley. Globalizations, 7(3), 383-393.

Christensen, C. M. (2013). The innovator's dilemma when new technologies cause great firms to fail. Boston, Massachusetts: Harvard Business Review Press.

de Ferranti, D., Perry, G. E., Lederman, D., \& Maloney, W. E. (2002). From Natural Resources to the Knowledge Economy: Trade and Job Quality.

Dy, A. M. (2017). At the Interfaces of Digital Entrepreneurship: Beyond Discourse, Towards a Realist Conceptualisation. Academy of Management Proceedings, 2017(1), 11848.

Dy, A. M., Martin, L., \& Marlow, S. (2018). Emancipation through digital entrepreneurship? A critical realist analysis. Organization, 25(5), 585-608.

Etzkowitz, H., \& Leydesdorff, L. (1995). The Triple Helix -- University-Industry-Government Relations: A Laboratory for Knowledge Based Economic Development (SSRN Scholarly Paper No. ID 2480085). Retrieved from Social Science Research Network

Fagerberg, J., Lundvall, B.-Å., \& Srholec, M. (2018). Global Value Chains, National Innovation Systems and Economic Development. The European Journal of Development Research, 30(3), 533-556. 
This is a peer-reviewed, accepted author manuscript of the following research article:

Wahome, M., \& Graham, M. (2020). Spatially shaped imaginaries of the digital economy. Information Communication and Society, 23(8), 1123-1138.

https://doi.org/10.1080/1369118X.2019.1701696

Freeman, C. (1995). The 'National System of Innovation' in historical perspective.

Cambridge Journal of Economics, 19(1), 5-24.

Gibson, W. F. (1989). Neuromancer (3. Aufl.). München: W. Heyne.

Graham, M. (2015). Contradictory Connectivity: Spatial Imaginaries and Technomediated

Positionalities in Kenya's Outsourcing Sector. Environment and Planning A:

Economy and Space, 47(4), 867-883.

Graham, M. (2016). Facebook is no charity, and the 'free' in Free Basics comes at a price.

Retrieved 4 December 2017, from The Conversation website:

http://theconversation.com/facebook-is-no-charity-and-the-free-in-free-basics-comesat-a-price-52839

Graham, M., Hjorth, I., \& Lehdonvirta, V. (2017). Digital labour and development: Impacts of global digital labour platforms and the gig economy on worker livelihoods:

Transfer: European Review of Labour and Research.

Haraway, D. (1988). Situated Knowledges: The Science Question in Feminism and the Privilege of Partial Perspective. Feminist Studies; College Park, Md., 14(3), 575-599.

Hsu, J.-Y. (2018). Hsinchu Technopolis: A Sociotechnical Imaginary of Modernity in Taiwan? Critical Sociology, 44(3), 487-501.

Jasanoff, S., \& Kim, S.-H. (2009). Containing the Atom: Sociotechnical Imaginaries and Nuclear Power in the United States and South Korea. Minerva, 47(2), 119-146.

Jasanoff, S., \& Kim, S.-H. (2016). Dreamscapes of modernity: Sociotechnical imaginaries and the fabrication of power. Chicago: The University of Chicago Press.

Kaplinsky, R., \& Keynes, M. (2011). “Bottom of the Pyramid Innovation” and Pro-Poor Growth (IKD Working Paper No. 62). Milton Keynes, UK: The Open University.

Lundvall, B.-Å. (2010). National systems of innovation: Toward a theory of innovation and interactive learning. London: Anthem Press. 
This is a peer-reviewed, accepted author manuscript of the following research article:

Wahome, M., \& Graham, M. (2020). Spatially shaped imaginaries of the digital economy. Information Communication and Society, 23(8), 1123-1138.

https://doi.org/10.1080/1369118X.2019.1701696

Massey, D. (1999). Imagining Globalization: Power-Geometries of Time-Space. In A. Brah,

M. J. Hickman, \& M. M. an Ghaill (Eds.), Global Futures: Migration, Environment and Globalization (pp. 27-44).

Massey, D. (2002). Globalisation: What does it mean for geography? Geography, 87(4), 293296.

Mavhunga, C. C. (2017). What Do Science, Technology, and Innovation Mean from Africa? MIT Press.

Mbembe, A. (2016a). Africa in the New Century. The Massachusetts Review, 57(1), 91-104.

Mbembe, A. (2016b). Decolonizing the university: New directions. Arts and Humanities in Higher Education, 15(1), 29-45.

Mosse, D. (2005). Cultivating Development: An Ethnography of Aid Policy and Practice. London, UK; Ann Arbor, MI, USA: Pluto Press.

Neveling, P. (2017). The political economy machinery: Toward a critical anthropology of development as a contested capitalist practice. Dialectical Anthropology, 41(2), 163183.

Ngoasong, M. Z. (2018). Digital entrepreneurship in a resource-scarce context. Journal of Small Business and Enterprise Development, 25(3), 483-500.

Obamba, M. (2012). Uncommon Knowledge: World Bank Policy and the Unmaking of the Knowledge Economy in Africa. Higher Education Policy, 26(1), 83.

Odumosu, T. (2009). Interrogating mobiles: A story of Nigerian appropriation of the mobile phone (ProQuest Dissertations Publishing). Retrieved from http://search.proquest.com/docview/304986497/?pq-origsite=primo

Pazarbasioglu, C. (2018, May 30). African leaders committed to building a digital economy [Text]. Retrieved 1 May 2019, from Voices-World Bank website: 
This is a peer-reviewed, accepted author manuscript of the following research article:

Wahome, M., \& Graham, M. (2020). Spatially shaped imaginaries of the digital economy. Information Communication and Society, 23(8), 1123-1138.

https://doi.org/10.1080/1369118X.2019.1701696

https://blogs.worldbank.org/voices/african-leaders-committed-to-building-digital-

economy

Pollock, N., \& Williams, R. (2016). How Industry Analysts Shape the Digital Future. Oxford, New York: Oxford University Press.

Porter, M. (1990). The competitive advantage of nations. London: Macmillan.

Punday, D. (2000). The Narrative Construction of Cyberspace: Reading Neuromancer, Reading Cyberspace Debates. College English, 63(2), 194-213.

Rajão, R., \& Duque, R. B. (2014). Between Purity and Hybridity: Technoscientific and Ethnic Myths of Brazil. Science, Technology, \& Human Values, 39(6), 844-874.

Sadowski, J., \& Bendor, R. (2019). Selling Smartness: Corporate Narratives and the Smart City as a Sociotechnical Imaginary. Science, Technology, \& Human Values, 44(3), $540-563$.

Sala-i-Martin, X., Bilbao-Osorio, B., Blanke, J., Hanouz, M. D., \& Geiger, T. (2011). The Global Competitiveness Index 2011-2012: Setting the Foundations for Strong Productivity. 48.

Saxenian, A. (1996). Regional advantage: Culture and competition in Silicon Valley and Route 128 (Paperback edition..). Cambridge, Mass. ; London: Harvard University Press.

Saxenian, A. (2006). The new argonauts: Regional advantage in a global economy. Cambridge, Mass.: Harvard University Press.

Selin, C. (2008). The Sociology of the Future: Tracing Stories of Technology and Time. Sociology Compass, 2(6), 1878-1895.

Solon, O. (2017, July 27). 'It's digital colonialism': How Facebook's free internet service has failed its users. The Guardian. Retrieved from 
This is a peer-reviewed, accepted author manuscript of the following research article:

Wahome, M., \& Graham, M. (2020). Spatially shaped imaginaries of the digital economy. Information Communication and Society, 23(8), 1123-1138.

https://doi.org/10.1080/1369118X.2019.1701696

https://www.theguardian.com/technology/2017/jul/27/facebook-free-basics-

developing-markets

Sparkes-Vian, C. (2019). Digital Propaganda: The Tyranny of Ignorance. Critical Sociology, 45(3), 393-409.

Steiber, A., \& Alänge, S. (2016). The Silicon Valley Model: Management for

Entrepreneurship. Cham: Springer International Publishing.

Storm, S. (2018). Financialization and Economic Development: A Debate on the Social Efficiency of Modern Finance. Development and Change, 49(2), 302-329.

Suchman, L. (2011). Anthropological Relocations and the Limits of Design. Annual Review of Anthropology, 40(1), 1-18.

Suchman, L., \& Bishop, L. (2000). Problematizing 'Innovation' as a Critical Project. Technology Analysis \& Strategic Management, 12(3), 327-333.

Welter, F. (2011). Contextualizing Entrepreneurship — Conceptual Challenges and Ways Forward. Entrepreneurship Theory and Practice, 35(1), 165-184.

Wiegratz, J. (2010). Fake capitalism? The dynamics of neoliberal moral restructuring and pseudo-development: the case of Uganda. Review of African Political Economy, 37(124), 123-137.

Woolley, S. C., \& Howard, P. N. (2018). Computational propaganda: Political parties, politicians, and political manipulation on social media. New York, NY: Oxford University Press. 